\title{
The Chemical Composition and Biological Activity of the Essential
}

Oil from the Underground Parts of Ferula tadshikorum

(Apiaceae)

\author{
Farukh S. Sharopov ${ }^{\oplus 1,2}$, Payrav D. Khalifaev ${ }^{\oplus 3}$, Prabodh Satyal ${ }^{\oplus 4,5}$, \\ Yanfang Sun ${ }^{\oplus 2,6}$, Abduahad Safomuddin ${ }^{\oplus 7}$, Safol Musozoda ${ }^{\oplus 3}$, \\ Michael Wink $^{\odot 2}$ and William N. Setzer ${ }^{\odot 4,5^{*}}$ \\ ${ }^{I}$ Department of Pharmaceutical Technology, Avicenna Tajik State Medical University, Rudaki 139, \\ 734003, Dushanbe, Tajikistan \\ ${ }^{2}$ Institute of Pharmacy and Molecular Biotechnology, Heidelberg University, Im Neuenheimer Feld \\ 364, Heidelberg 69120, Germany \\ ${ }^{3}$ Department of Pharmaceutical Technology and Biotechnology, National University of \\ Tajikistan, Rudaki 17/3, 734003, Dushanbe, Tajikistan \\ ${ }^{4}$ Department of Chemistry, University of Alabama in Huntsville, Huntsville, AL 35899, USA \\ ${ }^{5}$ Aromatic Plant Research Center, 615 St. George Square Court, Suite 300, Winston-Salem, \\ NC 27103, USA \\ ${ }^{6}$ College of Life Sciences, Zhejiang Sci-Tech University, Hangzhou 310018, China \\ ${ }^{7}$ Faculty of Chemistry, National University of Tajikistan, Rudaki 17/2, 734003, Dushanbe, \\ Tajikistan
}

(Received February 12, 2018; Revised March 19, 2018; Accepted March 20, 2018)

\begin{abstract}
The underground parts of Ferula tadshikorum M. Pimen were collected from the southern part of Tajikistan. The essential oils were obtained by hydrodistillation and analyzed by GLC-FID and GLC-MS. A total of 26 compounds were identified representing $94.4 \%$ of total oil composition. The essential oil was dominated by the sulfur-containing compounds (Z)-1-propenyl sec-butyl disulfide (37. 3\%), (E)-1-propenyl secbutyl disulfide (29.9\%), (E)-1-propenyl 1-(methylthio)propyl disulfide (16.8\%), and propyl sec-butyl disulfide $(4.8 \%)$. The antioxidant, antimicrobial and cytotoxic activities of the essential oil was evaluated. To our best knowledge, this is the first report concerning the chemical composition and biological activity of the essential oil obtained from the underground parts of F. tadshikorum.
\end{abstract}

Keywords: Ferula tadshikorum; essential oil composition; disulfides. C) 2018 ACG Publications. All rights reserved.

\section{Introduction}

The genus Ferula L. includes about 130 species in the family Apiaceae, the majority of species are widespread in Asia [1]. There are thirty-seven Ferula species present in Tajikistan. F. tadshikorum M. Pimen is an endemic plant of southern Tajikistan [2]. In recent years, due to the production of an

\footnotetext{
** Corresponding author: E-Mail: setzerw@uah.edu
}

The article was published by ACG Publications 
oleo-gum-resin (exudate) from Ferula species as asafoetida, interest in F. tadshikorum has also increased. The oleo-gum-resin is used for needs of the medical industry and as flavoring spice for various foodstuff. Approximately, the annual volume of exported oleo-gum-resin from Ferula species in Tajikistan is 150 tons [3]. The harvest in the wild is harmful and endangers populations of asafetidacontaining Ferula species, including F. tadshikorum.

Ferula species have been used as herbs since ancient time in traditional medicine. Avicenna recommended Ferula for treatment of skin diseases (vitiligo), tuberculosis, pains in joints, against worms, inflammation of stomach and intestines, and as an antidote for toxic salts and compounds [4]. In Tajik traditional medicine, asafoetida is used as an antispasmodic, antihelminthic, and carminative agent. Ferula is used to treat tumors and to rejuvenate the body [5].

Tadzhiferin and tadzhikorin, two terpenoid coumarins, have been isolated from the fruit of $F$. tadshikorum [6]. Later, deacetyltadzhikorin also was isolated from the acetone extract of the roots of F. tadshikorum [7]. Asafoetida has a characteristic sulfurous odor and a bitter taste, due to presence of sulfur-containing compounds [8]. Regarding the chemistry and bioactivity of the essential oil of $F$. tadshikorum, to our best knowledge, until now, there have been no published reports on volatile secondary metabolites of the underground parts of $F$. tadshikorum.

\section{Materials and Methods}

\subsection{Plant Materials}

The underground parts of $F$. tadshikorum M. Pimen were collected near the Guli Bodom village, Yovon region of Tajikistan (1000 m above sea level), on 15 June 2016, during the period of plant harvesting. The plant was identified by comparison with voucher specimen (MW0594029) which are deposited in the herbarium of the Lomonosov Moscow State University (Mosquensis University). The fresh samples from the underground parts of $F$. tadshikorum were cut into small pieces and hydrodistilled for $3 \mathrm{~h}$ to give the yellow essential oil, with $1.5 \%$ yield.

\subsection{Gas-liquid Chromatography}

The gas chromatographic analysis of the essential oil was performed using a GC-2010 plus gas chromatograph (Shimadzu), equipped with a non-polar ZB-5 fused bonded column (Phenomenex) and flame ionization detector (FID). The column parameters were $30 \mathrm{~m}$ length, $0.25 \mathrm{~mm}$ inner diameter and $0.25 \mu \mathrm{m}$ film thickness. The carrier gas was helium with a flow rate of $1.5 \mathrm{~mL} / \mathrm{min}$ with the split mode. The operating temperature conditions were initial temperature $120^{\circ} \mathrm{C}$ for 2 min isothermal followed by linear temperature increase until $320^{\circ} \mathrm{C}$ at a rate of $8^{\circ} \mathrm{C} / \mathrm{min}$, and then for $10 \mathrm{~min}$ at isothermal mode at $320^{\circ} \mathrm{C}$. Detector and injector temperatures were $320^{\circ} \mathrm{C}$ and $310^{\circ} \mathrm{C}$, respectively. GC solution by Shimadzu was used for recording and integration.

\subsection{Gas Chromatographic-Mass Spectral Analysis}

GLC-MS was performed using a Shimadzu GCMS-QP2010 Ultra operated in the electron impact $(\mathrm{EI})$ mode (electron energy $=70 \mathrm{eV}$ ), scan range $=40-400$ atomic mass units, scan rate $=3.0$ scans/s, and GC-MS solution software. The GC column was a ZB-5 fused silica capillary column with a (5\% phenyl)-polymethylsiloxane stationary phase and a film thickness of $0.25 \mu \mathrm{m}$. The carrier gas was helium with a column head pressure of $552 \mathrm{kPa}$ and flow rate of $1.37 \mathrm{~mL} / \mathrm{min}$. Injector temperature was $250^{\circ} \mathrm{C}$ and the ion source temperature was $200^{\circ} \mathrm{C}$. The $\mathrm{GC}$ oven temperature program was programmed for $50^{\circ} \mathrm{C}$ initial temperature, temperature increased at a rate of $2^{\circ} \mathrm{C} / \mathrm{min}$ to $260^{\circ} \mathrm{C}$. A $5 \% w / v$ solution of the sample in $\mathrm{CH}_{2} \mathrm{Cl}_{2}$ was prepared and $0.1 \mu \mathrm{L}$ was injected with a splitting mode (30:1). Identification of the oil components was based on their retention indices determined by reference to a homologous series of $n$-alkanes, and by comparison of their mass spectral fragmentation patterns with those reported in the literature [9], and stored in our in-house library [10]. 


\subsection{Antioxidant, Antimicrobial and Cytotoxicity Assays}

The antioxidant activity of the essential oil was evaluated by 2,2-diphenyl-1-picrylhydrazyl (DPPH), 2,2'-azino-bis-[3-ethylbenzthiazoline-6-sulfonic acid] (ABTS) and ferric reducing antioxidant power (FRAP) assays as described previously [11]. The essential oil was stabilized in Tween-80 and screened against methicillin-resistant Staphylococcus aureus (MRSA) NCTC 10442 and Escherichia coli ATCC 25922 bacteria [12]. Cytotoxicity of essential oil against CCRF-CEM (human T lymphoblast leukemia) and CEM/ADR5000 (adriamycin-resistant leukemia) cancer cell lines was determined by using 3-(4,5-dimethylthiazol-2-yl)-2,5-diphenyltetrazolium bromide (MTT) assay. Antioxidant, antimicrobial and cytotoxicity assays were analyzed as previously described [13].

\section{Results and Discussion}

\subsection{Essential Oil Composition}

The essential oil was and analyzed by GLC-FID and GLC-MS. A total of 26 compounds were identified representing $94.4 \%$ of total oil composition (Table 1). The essential oil was dominated by the sulfur-containing compounds (Z)-1-propenyl sec-butyl disulfide (37.3\%), (E)-1-propenyl sec-butyl disulfide $(29.9 \%)$, (E)-1-propenyl 1-(methylthio)propyl disulfide $(16.8 \%)$, and propyl sec-butyl disulfide (4.8\%) (Figure 1).

Table 1. Chemical composition of the essential oil of the underground parts of Ferula tadshikorum.

\begin{tabular}{|c|c|c|c|}
\hline $\mathbf{R I}^{\mathbf{a}}$ & $\mathbf{R I}^{\mathbf{b}}$ & Compound & $\%$ \\
\hline 860 & 860 & 2-Methyloctane & 0.2 \\
\hline 900 & 900 & Nonane & $\mathrm{t}$ \\
\hline 925 & 926 & Tricyclene & $\mathrm{t}$ \\
\hline 932 & 939 & $\alpha$-Pinene & 0.8 \\
\hline 949 & 954 & Camphene & 0.1 \\
\hline 968 & 973 & 2-Pyrone & 0.2 \\
\hline 978 & 979 & $\beta$-Pinene & 0.4 \\
\hline 989 & 990 & Myrcene & 0.1 \\
\hline 995 & --- & Methyl sec-butyl disulfide & $\mathrm{t}$ \\
\hline 1010 & 1010 & 2,3,5-Ttrimethylthiophene & $\mathrm{t}$ \\
\hline 1017 & 1017 & $\alpha$-Terpinene & $\mathrm{t}$ \\
\hline 1024 & 1024 & $p$-Cymene & $\mathrm{t}$ \\
\hline 1029 & 1029 & Limonene & $\mathrm{t}$ \\
\hline 1035 & 1037 & $(Z)$ - $\beta$-Ocimene & 0.3 \\
\hline 1045 & 1050 & (E)- $\beta$-Ocimene & 0.5 \\
\hline 1058 & 1059 & $\gamma$-Terpinene & $\mathrm{t}$ \\
\hline 1108 & 1103 & Dipropyl disulfide & 0.1 \\
\hline 1164 & 1164 & Propyl sec-butyl disulfide & 4.8 \\
\hline 1169 & 1169 & (Z)-1-Propenyl sec-butyl disulfide & 37.3 \\
\hline 1174 & --- & (E)-1-Propenyl sec-butyl disulfide & 29.9 \\
\hline 1212 & 1212 & Di-sec-butyl disulfide & 0.5 \\
\hline 1421 & 1421 & (Z)-1-Propenyl 1-(methylthio)propyl disulfide & 2.5 \\
\hline 1427 & 1427 & (E)-1-Propenyl 1-(methylthio)propyl disulfide & 16.8 \\
\hline 1452 & 1456 & $(E)-\beta$-Farnesene & $\mathrm{t}$ \\
\hline \multirow[t]{5}{*}{1503} & 1505 & $(E, E)-\alpha$-Farnesene & 0.3 \\
\hline & & Terpenoids & 2.5 \\
\hline & & Sulfur-containing compounds & 91.8 \\
\hline & & Others & 0.2 \\
\hline & & Total identified & 94.4 \\
\hline
\end{tabular}

${ }^{a}$ Retention Index (RI) determined with reference to a homologous series of $n$-alkanes on a ZB-5 column.

${ }^{\mathrm{b}}$ Retention Index from the databases $[9,10]$. t:trace 


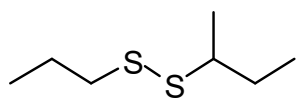

Propyl sec-butyl disulfide

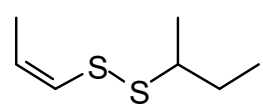

(Z)-1-propenyl sec-butyl disulfide

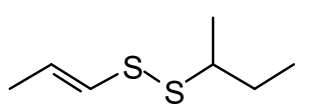

(E)-1-propenyl sec-butyl disulfide

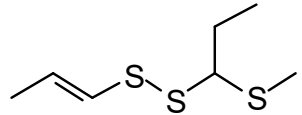

(E)-1-propenyl 1(methylthio)propyl disulfide

Figure 1. Structure of the major components of the essential oil of Ferula tadshikorum.

According to literature reports, the sulfur-containing compounds are the major components of the essential oils of many Ferula species, including $F$. assa-foetida [14], F. fukanensis [15], F. latisecta [16,17], F. persica [18,19] and $F$. sinkiangensis [15]. The most prevalent sulfur-containing compounds in the Ferula oils were (Z)-1-propenyl sec-butyl disulfide and (E)-1-propenyl sec-butyl disulfide [20], which is in agreement with the F. tadshikorum essential oil composition.

\subsection{Antioxidant, Antimicrobial and Cytotoxic Activities}

The essential oil of F.tadshikorum exhibited low antioxidant activity as compared to the positive control, caffeic acid. The results of the DPPH, ABTS and FRAP analyses are represented Table 2. Median inhibitory concentration $\left(\mathrm{IC}_{50}\right)$ for radical scavenging of the essential oil was 17.8 $\mathrm{mg} / \mathrm{mL}$ for DPPH and $8.2 \mathrm{mg} / \mathrm{mL}$ for ABTS, respectively. The ferric reducing antioxidant power value was $1072.4 \mu \mathrm{M} \mathrm{Fe}(\mathrm{II}) / \mathrm{mg}$ of the oil sample.

Table 2. Antioxidant and cytotoxic activities of the essential oil of Ferula tadshikorum.

\begin{tabular}{cccccc}
\hline Sample & $\begin{array}{c}\mathrm{DPPH} \\
\mathrm{IC}_{50}, \mathrm{mg} / \mathrm{mL}\end{array}$ & $\begin{array}{c}\mathrm{ABTS} \\
\mathrm{IC}_{50}, \mathrm{mg} / \mathrm{mL}\end{array}$ & $\begin{array}{c}\text { FRAP } \\
\mu \mathrm{M} \mathrm{Fe}(\mathrm{II}) / \mathrm{mg} \text { of } \\
\text { samples }\end{array}$ & $\begin{array}{c}\mathrm{CCRF}-\mathrm{CEM} \\
\mathrm{IC}_{50}, \mu \mathrm{g} / \mathrm{mL}\end{array}$ & $\begin{array}{c}\mathrm{CEM} / \mathrm{ADR} \\
5000 \\
\mathrm{IC}_{50}, \mu \mathrm{g} / \mathrm{mL}\end{array}$ \\
\hline $\begin{array}{c}\text { F. tadshikorum } \\
\text { essential oil } \\
\text { Positive control }\end{array}$ & 17.8 & 8.2 & 1072.4 & 21.6 & 142.5 \\
\hline
\end{tabular}

${ }^{\mathrm{a}}$ Caffeic acid, ${ }^{\mathrm{b}}$ doxorubicin

The antimicrobial activity of the essential oil was screened against one Gram-positive and one Gram-negative bacteria (MRSA NTCT 10442 and E. coli ATCC 25922). The essential did not exhibit antimicrobial activity at a concentration $20 \mathrm{mg} / \mathrm{mL}$. Our results indicate that the essential oil has weak antioxidant and antimicrobial activities, similar to other sulfur-containing Ferula oils [21].

The cytotoxicity of the oil was tested against CCRF-CEM and CEM/ADR5000 cancer cell lines: $\mathrm{IC}_{50}$ values were $21.6 \mu \mathrm{g} / \mathrm{mL}$ for CCRF-CEM, and $142.5 \mu \mathrm{g} / \mathrm{mL}$ for CEM/ADR5000 cell lines. $\mathrm{CEM} / \mathrm{ADR} 5000$ over-expresses the $\mathrm{ABC}$ transporter p-gp. The reduced cytotoxity of the essential oil suggests that it contains substrates of p-gp, which would be rapidly pumped out of the cells. Bagheri and co-workers reported that methanol extracts of different Ferula species and the oleo-gum-resin of F. assa-foetida exhibited cytotoxic effect with $\mathrm{IC}_{50}$ values in the range of 6-321 $\mu \mathrm{g} / \mathrm{mL}$ [22].

In conclusion, this work is the first report concerning the chemical composition and biological activity of the essential oil of the underground parts of F. tadshikorum. The chemical compositions of the essential oil were dominated by the sulfur-containing compounds $(Z)$-propenyl sec-butyl disulfide, (E)-propenyl sec-butyl disulfide and (E)-1(1-propen-1-yl)-2(2-thiopent-3-yl) trans disulfide. These components have been found in essential oils of several other Ferula species as major constituents. The cytotoxicity of the essential oil against CCRF-CEM and CEM/ADR5000 cancer cell lines is in agreement with its traditional use as antitumor drug. 


\section{Acknowledgments}

F.S.S. is grateful to the joint scholarship program of the German Academic Exchange Service (DAAD) and the University of Central Asia (UCA). P.S. and W.N.S. participated in this work as part of the activities of the Aromatic Plant Research Center (APRC, https://aromaticplant.org/). The authors are grateful to dōTERRA International (https://www.doterra.com/US/en) for financial support of the APRC. The authors declare no conflicts of interest.

\section{ORCID}

Farukh S. Sharopov: 0000-0003-0378-8887

Payrav Khalifaev: 0000-0002-7148-1695

Prabodh Satyal: 0000-0002-2950-1074

Yanfang Sun: 0000-0003-2704-0478

Abduahad Safomuddin: 0000-0001-9553-8302

Safol Musozoda: 0000-0001-8512-8019

Michael Wink: 0000-0002-7875-4510

William N. Setzer: 0000-0002-3639-0528

\section{References}

[1] D. J. Mabberley (2008). Mabberley's Plant-Book. Cambridge University Press.

[2] K. S. Rahmonov (2017). Biology and Resources of Ferula tadshikorum M. Pimen. in the South of Tajikistan. Ph.D. dissertation, Tajik National University.

[3] S. Rakhimov and G. R. Denisova (2017). Some features of underground organs of Ferula tadshikorum M. Pimen (Ferula L.), Bull. Altai State Agric. Univ. 154, 86-90.

[4] A. A. Sina (Avicenna) (reprinted in 1954). Kanon vrachebnoy nauki (Canon). Academy of Sciences of the UzSSR.

[5] M. Tohiri (2012). Ferula Treats Tumors and Rejuvenates a Body (Ферула лечит опухоли и омолаживает тело), 5th Ed. Tib, Dushanbe, Tajikistan, 32 pp.

[6] M. E. Perelson, Y. E. Sklyar, V. V. Vandyshev, K. Verkhovska-Renke, N. V. Veselovskaya and M. G. Pimenov (1976). New terpenoid coumarins from Ferula tadshikorum, Chem. Nat. Comp. 5, 592-593.

[7] N. V. Beselovskaya and E. Y. Sklyar (1984). Deacetyltadzhikorin from Ferula tadshikorum, Chem. Nat. Comp. 3, 386-387.

[8] M. Iranshahy and M. Iranshahi (2011). Traditional uses, phytochemistry and pharmacology of asafoetida (Ferula assa-foetida oleo-gum-resin)-A review, J. Ethnopharmacol.134, 1-10.

[9] R. P. Adams (2007). Identification of Essential Oil Components by Gas Chromatography / Mass Spectrometry. 4th Ed. Allured Publishing, Carol Stream, Illinois.

[10] P. Satyal (2015). Development of GC-MS Database of Essential Oil Components by the Analysis of Natural Essential Oils and Synthetic Compounds and Discovery of Biologically Active Novel Chemotypes in Essential Oils. PhD dissertation, University of Alabama in Huntsville.

[11] F. S. Sharopov, M. Wink and W. N. Setzer (2015). Radical scavenging and antioxidant activities of essential oil components - an experimental and computational investigation, Nat. Prod. Commun. 10, 153-156.

[12] F. Sharopov, M. S. Braun, I. S. Gulmurodov, D. R. Khalifaev, S. J. Isupov and M. Wink (2015). Antimicrobial, antioxidant, and anti-inflammatory activities of essential oils of selected aromatic plants from Tajikistan, Foods 4, 645-653.

[13] F. S. Sharopov (2015). Phytochemistry and Bioactivities of Selected Plant Species with Volatile Secondary Metabolites. Ph.D. thesis, Ruperto-Carola University of Heidelberg.

[14] M. Khajeh, Y. Yamini, N. Bahramifar, F. Sefidkon and M. Reza Pirmoradei (2005). Comparison of essential oils compositions of Ferula assa-foetida obtained by supercritical carbon dioxide extraction and hydrodistillation methods, Food Chem. 91, 639-644.

[15] M. Zhi-da, M. Qi-fi, M. Mizuno, T. Tanaka and M. Iinuma (1987). Polysulfanes in the volatile oil of Ferula species, Planta Med. 53, 300-302. 
[16] Z. Habibi, P. Salehi, M. Yousefi, Y. Hejazi, A. Laleh, V. Mozaffarian, S. Masoudi and A. Rustaiyan (2006). Chemical composition and antimicrobial activity of the essential oils of Ferula latisecta and Mozaffariania insignis from Iran, Chem. Nat. Comp. 42, 689-692.

[17] M. Iranshahi, M. Hassanzadeh-Khayat, B. S. F. Bazzaz, Z. Sabeti and F. Enayati (2008). High content of polysulphides in the volatile oil of Ferula latisecta Rech. F. et Aell. fruits and antimicrobial activity of the oil, J. Essent. Oil Res. 20, 183-185.

[18] M. Iranshahi, G. Amin, M. H. Salehi-Sourmaghi, A. Shafiee and A. Hadjiakhoondi (2006). Sulphurcontaining compounds in the essential oil of the root of Ferula persica Willd. var. persica, Flavour Fragrance J. 21, 260-261.

[19] K. Javidnia, R. Miri, M. Kamalinejad and N. Edraki (2005). Chemical composition of Ferula persica Wild. essential oil from Iran, Flavour Fragrance J. 20, 605-606.

[20] A. Sahebkar and M. Iranshahi (2011). Volatile constituents of the genus Ferula (Apiaceae): a review, $J$. Essent. Oil Bear. Plants 14, 504-531.

[21] G. Kavoosi and V. Rowshan (2013). Chemical composition, antioxidant and antimicrobial activities of essential oil obtained from Ferula assa-foetida oleo-gum-resin: Effect of collection time, Food Chem. 138, 2180-2187.

[22] S. M. Bagheri, A. Sahebkar, A. R. Gohari, S. Saeidnia, M. Malmir and M. Iranshahi (2010). Evaluation of cytotoxicity and anticonvulsant activity of some Iranian medicinal Ferula species, Pharmaceut. Biol. 48, 242-246.

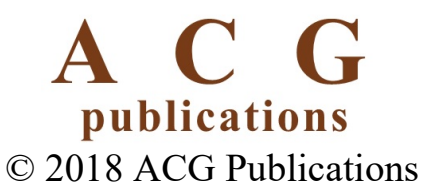

